Article

\title{
Feasibility Study on Energy Audit and Data Driven Analysis Procedure for Building Energy Efficiency: Bench-Marking in Korean Hospital Buildings
}

\author{
Dong Kon Hwang ${ }^{1}$, Jinkyun Cho ${ }^{2, * \mathbb{D}}$ and Junghwan Moon ${ }^{3}$ \\ 1 Department of Mechanical \& Information Engineering, University of Seoul, Seoul 02504, Korea \\ 2 Department of Building and Plant Engineering, Hanbat National University, Daejeon 34158, Korea \\ 3 Department of Building System Technology, Daelim University College, Anyang 13916, Korea \\ * Correspondence: jinkyun.cho@hanbat.ac.kr; Tel.: +82-42-821-1183
}

Received: 2 June 2019; Accepted: 29 July 2019; Published: 3 August 2019

\begin{abstract}
Growths in population, increasing demand for health care services and comfort levels, together with patients on the rise in time spent inside hospitals, assure the upward trend that energy demand will continue in the future. Since the hospital buildings operate 24 hours, 365 days a year for the treatment and restoration of patients, they are approximately 2-3 times more energy-intensive than normal buildings. For this reason, energy efficiency in hospitals is one of the prime objectives for energy policy at regional, national and international levels. This study aims to find how meaningful energy performance, reflecting good energy management and energy conservation measures (ECMs), can be operated for hospital buildings, a category encompassing complex buildings with different systems and large gaps between them. Energy audit allows us to obtain knowledge from the healthcare facility, in order to define and tune data driven analysis rules. The use of benchmarking in the energy audit of healthcare facilities enables immediate comparison between hospitals. Data driven energy analysis also allows ascertaining their expected energy consumption and estimating the possible savings margin by using the building energy flow chart. In the 2015-2017 periods, bench-marking of four public hospitals in Seoul were audited for the energy consumption related to weather conditions, total area, bed numbers, employee numbers, and analyzed for building energy flow by zones, energy sources, systems and equipment. This is a practice-based learning in a hospital project. The results reveal that the average annual energy consumption of a hospital under normal conditions, and energy efficiency factors are divided into energy baselines, energy consumption goals for energy saving and energy usage trends for setting ECMs, respectively. The indicator dependent on the area of inpatients (number of beds) proved to be the most suitable as a reference to quantify the energy consumption of a hospital.
\end{abstract}

Keywords: hospital facility; ECMs: Energy conservation measures; energy audit; energy analysis; building energy flow chart

\section{Introduction}

\subsection{Background and Objectives}

Globally, a new obligation of greenhouse gas reduction and energy saving is assigned through a climate change agreement. At the 2015 United Nations Climate Change Conference (COP 21), South Korea announced a $37 \%$ reduction goal based on the 2030 greenhouse gas emission forecast (BAU), whereby the main target is a reduction of energy use in the building. The energy consumption in the building sector is about $25 \%$ of total energy use in South Korea [1], and $20-40 \%$ based on that of the OECD countries [2]. In Seoul, it is 55.9\% in 2013, which is larger than the usual proportion 
of building energy use in advanced countries and South Korea [3]. Since the hospital buildings operate 24 hours, 365 days a year for the treatment and restoration of patients, they are approximately 2-3 times more energy-intensive than normal buildings [4]. It is extremely difficult to reduce the energy consumption, because spaces that have various operating hours and usage patterns co-exist, such as wards, outpatient clinic, operating rooms, ICU (intensive care unit), offices, and convenience facilities, there is a characteristic that the cooling/heating load ratio and fluctuation are complex. HVAC (heating, ventilation, and air condition) is the main end use with a weight close to $50 \%$, lighting follows with $15 \%$ and medical devices with 10\% [5]. Nevertheless, in most cases, hospital buildings' HVAC systems are designed and operated relatively simply in comparison with the use and size, and the patient-oriented environment is maintained, the energy saving technique is carried out manually [6]. The energy performance of buildings needs to be monitored and maintained. A well-developed energy management system in the building can help to identify failures in a timely manner and reduce excessive energy consumption. This study attempts to introduce awareness on potential energy savings in hospitals. This research constructs an energy audit procedure and systematizes the evaluation method to investigate the building energy flow from the operation of HVAC systems lighting and medical devices. The data driven analysis methodology used in this study is based on the benchmarking analysis.

\subsection{Research Methodology and Procedure}

This is a practice-based learning in a hospital project. The differences and special features of this study is that four different forms of hospital facilities were evaluated based on the same energy factors of usage category and the same evaluation method for the energy flow chart. With this accomplishment, the reliability of comparison has made it possible to overcome previous experimental and simulation researches. In order to evaluate the efficiency of HVAC, lighting and medical devices that can be used in hospital buildings, a basic energy flow analysis methodology was set up, and various sources of energy data were analyzed. Furthermore, the method of analysis that was carried out in this study highlights how to plan and conduct an energy audit and data driven analysis toward utilizing the BEMS (building energy management system). As a preliminary step, the study requires developments of the energy audit and data driven analysis procedure. Based on this procedure, an easy to use relevant checking factor for the energy audit of hospital buildings was developed. Additionally it helps in understanding the building energy demands in the operating stage of hospital building diagnosis. Finally, targeting four hospitals located in Seoul, energy usage characteristics are derived by on-site investigations and comparison of operation data analysis results. In addition, this study proposes a stage of classifying the ECMs suitable for hospital buildings.

\section{Related Work}

The building type is critical in how energy end uses are distributed and in their energy intensity (Table 1) [7]. This makes it essential to develop independent studies by building types. Hospitals are the most energy intensive typologies with typically average energy use intensity of over $423 \mathrm{kWh} / \mathrm{m} 2$ of the annual energy consumption. Hotels and retails, offices and schools follow. In Seoul, because there are many large buildings such as hospitals, hotels, office buildings, and department buildings, the energy consumption proportion of high energy consumption buildings (facilities consuming the energy of more than 2000 TOE annually) is very big, as shown in Figure 1. 
Table 1. Average energy use intensity by building type in Korea. [7].

\begin{tabular}{cccccccc}
\hline Year & Energy & Offices & Retails & Schools & Hotels & Hospitals & Dwellings \\
\hline 2007 & $\begin{array}{c}\text { Total energy use } \\
\left(\mathrm{kWh} / \mathrm{m}^{2}\right)\end{array}$ & 281 & 414 & 210 & 487 & 490 & 162 \\
& $\begin{array}{c}\text { Electricity consumption } \\
\left(\mathrm{kWh} / \mathrm{m}^{2}\right)\end{array}$ & 179 & 293 & 121 & 223 & 203 & 41 \\
\hline $\begin{array}{c}\text { Total energy use } \\
\left(\mathrm{kWh} / \mathrm{m}^{2}\right)\end{array}$ & 245 & 274 & 210 & 390 & 467 & 145 \\
\hline $\begin{array}{c}\text { Electricity consumption } \\
\left(\mathrm{kWh} / \mathrm{m}^{2}\right)\end{array}$ & 140 & 170 & 106 & 147 & 172 & 34 \\
$\quad \begin{array}{c}\text { Total energy use } \\
\left(\mathrm{kWh} / \mathrm{m}^{2}\right)\end{array}$ & 222 & 231 & 190 & 341 & 423 & 127 \\
\hline $\begin{array}{c}\text { Electricity consumption } \\
\left(\mathrm{kWh} / \mathrm{m}^{2}\right)\end{array}$ & 150 & 174 & 120 & 151 & 192 & 37 \\
\hline
\end{tabular}

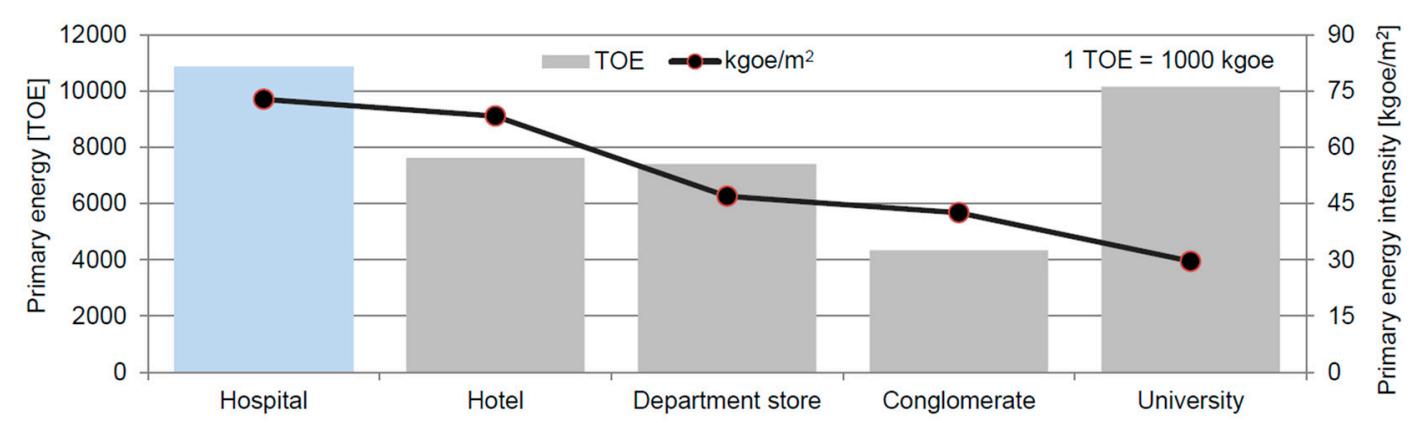

Figure 1. Energy consumption characteristics by building types in Seoul, Korea. [8].

Among them, the hospital building is one of highest energy consumption building types and has the highest primary energy intensity of $72.9 \mathrm{kgoe} / \mathrm{m}^{2}$ [8]. Reviewing the literature, some examples of research on the data analysis for improving energy efficiency in hospital buildings can be found. For the energy audit and analysis process for energy saving, many studies have been carried out based on office buildings among the residential and non-residential buildings. However, for hospital buildings that have high energy consumption, relatively few studies have been conducted compared to the importance with respect to the energy audit method and management process considering the special characteristics and operating condition. Cho et al. $[9,10]$ analyzed the characteristics and performance of the inpatient HVAC system of the hospital building in the aspect of combined concept that focused on the system configuration and climate characteristics; and at the same time, analyzed the energy effect according to the FCU (fan coil unit)+DOAS (dedicated outdoor air system), chilled beam+DOAS, and CAV (constant air volume) and VAV (variable air volume) systems. Moreover, a simulation-based methodology was derived, which can analyze the energy consumption effect according to the components of the HVAC system of the hospital building. Based on this, the energy characteristics and performance of the HVAC system were analyzed and the effect on energy was also analyzed for the respective composing systems and climate regions. Biglia et al. [11] implemented a process of investigating the energy reduction performance of the multi-heat sources system of the hospital building based on a CHP (Combined Heat and Power) system by combining dynamic energy simulation and experimental data based on an energy hub modeling framework. To apply an energy efficiency improvement technique to Chinese hospitals, Wang et al. [12] analyzed specific problems in economic, technical, and political aspects for 20 major hospitals, and studied the technology application method from the administrator perspective through the survey evaluation. Christiansen et al. [13] analyzed the electric energy consumption of the hospital and large medical devices by considering the special characteristics of the hospital. To estimate the energy demand of medical devices, data of more than 20,000 $\mathrm{h}$ were measured and analyzed for operating rooms, ICUs, and medical treatment rooms, and proposed a methodology for electric power usage prediction based on time and detailed operating hour reviews. Furthermore, to investigate the energy saving through various control techniques, Congradac et al. [14] selected a methodology 
for achieving independence and high efficiency of the energy consumption evaluation and proposed specific settings and an execution plan of the management method as a tool for energy consumption estimation. Ascione et al. [15] developed an algorithm to solve the problem of theoretical methodology for energy improvement and cost optimization for optimization of the multi-system in stages for the energy audit of the hospital building. González et al. [16] analyzed data of 2005-2014 for 20 hospitals in Spain to derive the correlation between the hospital energy consumption, climate condition, GDP, building envelop area, number of beds, and number of employees: The annual energy consumption was $0.27 \mathrm{MWh} / \mathrm{m}^{2}, 10 \mathrm{MWh} /$ worker, and $35 \mathrm{MWh} /$ bed. Teke and Timur [17] analyzed the complex economic efficiency of HVAC system including applicable VRF, CHP, waste heat recovery exchanger, and steam heat recovery technology for energy reduction potentials and energy efficiency related to the hospital HVAC system. Vanhoudt et al. [18] performed a long-term experimental evaluation of energy and cost reduction for the heat pump and water heat storage system using groundwater of hospitals in Belgium.

Through monitoring for more than three years, it was analyzed that the energy consumption was decreased by $71 \%$ compared to the gas boiler and water chiller unit, and $\mathrm{CO}_{2}$ reduction of 1280 tons was derived. Ma et al. [19] analyzed the energy consumptions and characteristics of 119 public buildings located in north China. The results showed that among the offices, hospitals, and schools, the hospitals were using the energy more than two times, and it was evaluated that the HVAC, lighting density, and building envelope had the largest effect on the energy consumption. Furthermore, in a study related to the facility system control of the hospital, Papantoniou et al. [20] applied a Web-based real-time multi-system optimization technique based on a weather prediction model, which is an optimal control algorithm of artificial neural net BOC (building optimization and control), to the installed BEMS (building energy management system) in hospitals in Greece. Lee and Cheng [21] performed a statistical analysis on the energy reduction effect evaluation for 305 EMS (energy management system) case studies (105 BEMS, 200 EMS) reported from 1976 to 2014. As a result, 39.5\% of average reduction was shown in the lightings and about $14.1 \%$ reduction effect was derived in the HVAC systems. Shen et al. [22] selected a typical comprehensive hospital in the hot summer and cold winter area as a case, analyzed the actual energy demand of the hospital building through the measured data, and put forward reasonable suggestions on the energy consumption mode and system improvement plan of the hospital in combination with the operating conditions. Thinate et al. [23] studied on the initial energy assessment and the finding of the baseline setting of the energy consumption of buildings in the commercial, emphasizing on the hospital groups. Multiple linear regression analysis is introduced to analyze factors affecting energy consumption, which leads to the baseline setting analysis of energy consumption of large hospital buildings. Alonso et al. [24] proposed a data-driven analysis for improving the efficiency in multiple-chiller plants of a hospital. Data analysis, based on aggregation operations, filtering and data projection, allows obtaining knowledge from chillers and the whole plant, in order to define and tune management rules. González et al. [25] studied on benchmarking in the management of healthcare facilities enables immediate comparison between hospitals. The indicator dependent on the number of beds proved to be the most suitable as a reference to quantify the energy consumption of a hospital. González et al. [26] analyzed the impact of maintenance management on the energy consumption of a hospital and to look for existing relationships between the time spent on maintenance operations and the energy consumption of the building.

As shown above, technologies have been applied and evaluated for energy savings of hospitals, but because these studies reflected the special characteristics of corresponding buildings, it is difficult to apply them commonly and obtain the same effects. Therefore, the management target facility system selection and management standard of the hospital building should be examined first and a universal energy audit method of the hospital building should be systematized and its process should be developed by clarifying the energy-related factors according to the facility system composition. 


\section{Development of Energy Audit Method for Hospital Buildings}

The energy audit of the hospital building requires the collection of energy data based on the investigation results of the target hospital, and analysis of the consumption pattern and performance by energy usage scenario based on the analysis scope determined by using the collected specific data. In other words, energy-saving operation factors are discovered based on the energy performance analysis results of the target hospital, and similarities with other hospital buildings and generalizable items are derived. As shown in Figure 2, there are three steps for the general procedure of the data-driven energy analysis for hospital buildings; step 1 for the fact finding survey, step 2 for energy analysis by BEMS and step 3 for energy saving items.

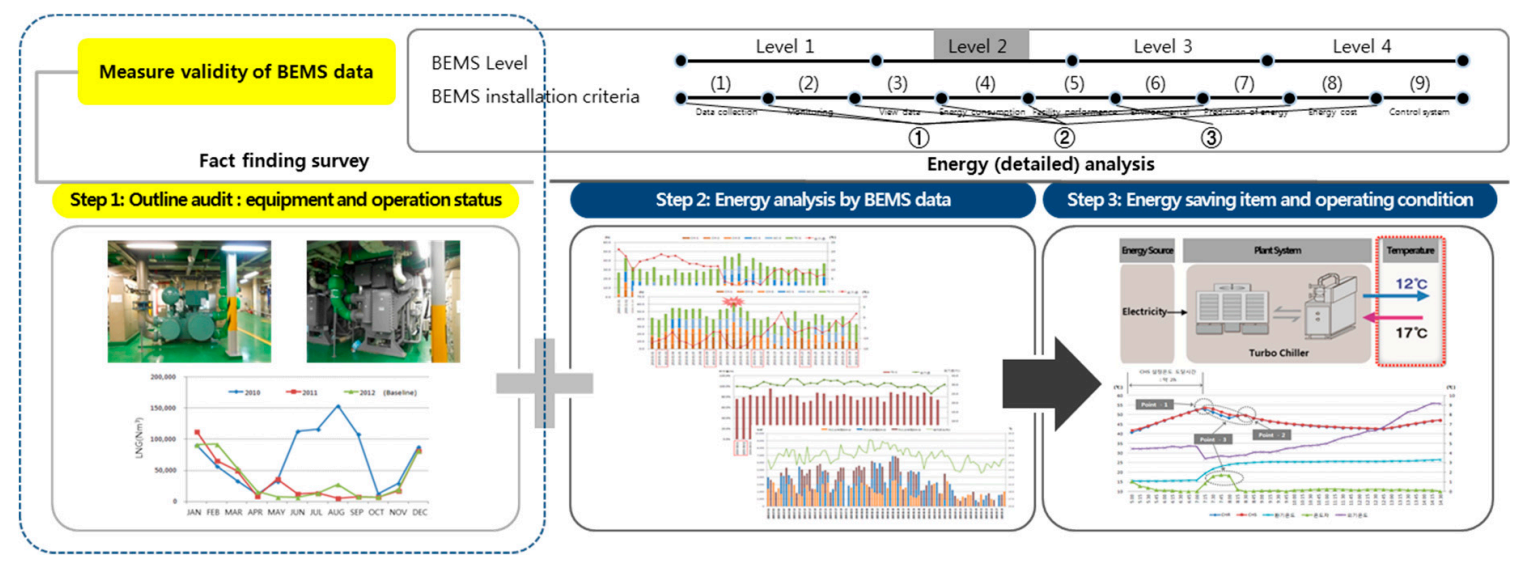

Figure 2. General procedure of data-driven energy analysis for hospital buildings.

\subsection{Stage 1: On-Site Investigation and Preliminary Energy Audit}

With the BEMS, there is a deluge of building energy data. This data has been leveraged for a variety of applications. First, it is necessary to determine the validity of collectible data for the energy audit of the hospital building, and the scope of data collection and analysis should be set up through the BEMS installation level of the target building. The BEMS level can be classified by the energy data collection form from the remote energy monitoring. To this end, it is important to investigate the method that can achieve the reduction of energy usage and operating cost in a short period through on-site visitation at the target hospital building. Therefore, through the overall current status investigation for the target building and interviews with the building users and managers, a process of conceptually understanding the building and the energy performance of the building should be performed. Based on this, the major equipment status, energy usage pattern by the purpose of use, operating method of equipment, zoning, the purpose of use, number of people visiting, and usage characteristics according to time should be identified. Table 2 shows the BEMS level classification and installation criteria for the selection and analysis of the target hospital. The BEMS installation criteria are for the function requirement that building managers need both to understand the energy usage of their buildings and to control and improve their buildings' energy performance. According to the BEMS level, the possible scope of the energy audit is determined for each energy source and purpose of use, or specifically, for each device and zone. The point of view from the energy measuring level 1 to level 4 is moving from an easy to struggle, this is from the energy source to the equipment responsible for that energy consumption. And level 4 is more difficult to measure the energy consumption by zones such as outpatient, operating theater, etc. 
Table 2. Classification of building energy management system (BEMS) level and installation criteria.

\begin{tabular}{|c|c|c|c|}
\hline Level & Energy Analysis & Data Collection & Main Function \\
\hline 1 & $\begin{array}{l}\text { By energy sources } \\
\text { (electricity, gas, etc.) }\end{array}$ & $\begin{array}{l}\text { BAS } \\
\text { Basic energy-saving control }\end{array}$ & $\begin{array}{l}\text { BAS energy-saving function } \\
\text { - Enthalpy control } \\
\text { - Optimum start/stop control } \\
\text { - Operating number control } \\
\text { - } \mathrm{CO}_{2} \text { control }\end{array}$ \\
\hline 2 & $\begin{array}{l}\text { By systems } \\
\text { (heating, cooling etc.) }\end{array}$ & $\begin{array}{l}\text { BAS + EMS } \\
\text { Energy management system }\end{array}$ & $\begin{array}{l}\text { Level } 1+\text { Energy trend analysis } \\
\text { - Energy consumption } \\
\text { - Energy demand trend } \\
\text { - Energy change analysis }\end{array}$ \\
\hline 3 & $\begin{array}{l}\text { By equipment } \\
\text { (chiller, boiler, etc.) }\end{array}$ & $\begin{array}{l}\text { BAS }+ \text { EMS }+\alpha \\
\text { Energy performance management }\end{array}$ & $\begin{array}{l}\text { Level } 1+2+\text { Equipment performance } \\
\text { - Energy over-consumption } \\
\text { - Fault detection }\end{array}$ \\
\hline 4 & $\begin{array}{l}\text { By zones } \\
\text { (ward, outpatient, etc.) }\end{array}$ & $\begin{array}{l}\text { BAS }+ \text { EMS }+\alpha+\beta \\
\text { Energy optimization system }\end{array}$ & Level $1+2+3+$ Optimization control \\
\hline \multicolumn{4}{|c|}{ BEMS installation criteria } \\
\hline \multicolumn{2}{|c|}{ (1) Data collection and display } & (2) Information monitoring & (3) View data \\
\hline \multicolumn{2}{|c|}{ (4) Analysis of energy usage status } & (5) Analysis of facility efficiency & (6) Providing in/outdoor information \\
\hline \multicolumn{2}{|c|}{ (7) Prediction of energy consumption } & (8) Energy cost inquiry and analysis & (9) Interlocking control system \\
\hline
\end{tabular}

According to the type and scope of the data acquired through automatic controls, the energy analysis method and control level can be extended from simple maneuvers/operating number control to the scope of energy trend analysis, prediction, deterioration energy audit, and optimal control.

\subsection{Stage 2: Data Collection from Remote Energy Monitoring}

After the remote monitoring scope is determined based on the preliminary investigation, the next stage is important, i.e., the process of collecting the history data of process and operation information, which affect the energy consumption of the hospital, and the measurement data on energy flows through component equipment (systems). As shown in Figure 3, the possible data collection and query scopes are clearly defined by energy sources of the target building (LNG, electricity, district heating, etc.), by equipment (chiller, boiler, AHU (air handling unit) and lighting, etc.), by purpose of use/system (cooling, heating, hot water, ventilation, lighting, etc.), and by hospital zones (inpatient, outpatient service, operating rooms, ICU, emergency center, common facility, etc.). Moreover, the data are collected by classifying them into the real-time evaluation and period evaluation based on the evaluation time of performance-related factors measured and collected by the remote monitoring system.

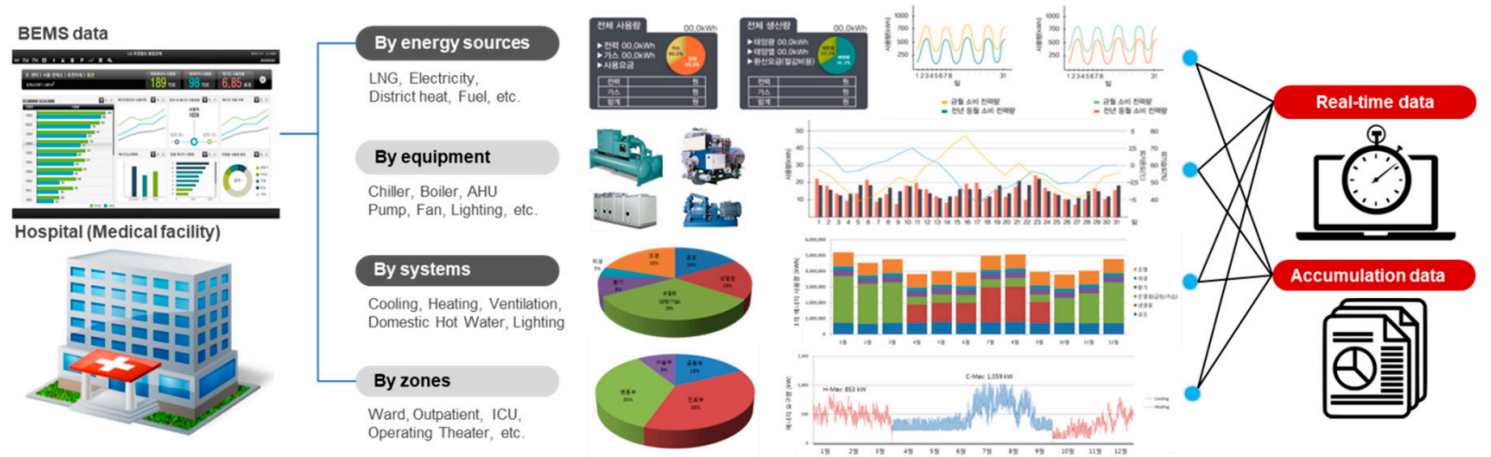

Figure 3. Data collection procedure from the remote energy monitoring system.

\subsection{Stage 3: Selection of Energy-Related Factors and Performance Evaluation Items}

To diagnose-evaluate the energy of the hospital, the energy-related factors of HVAC should be set up and the measurement method should be considered for the factors not measured in the BEMS. 
Table 3 corresponds to the most basic factors for building energy usage analysis. These factors are the same as the computation factors required for building energy simulation. Ultimately, a series of energy flows from the energy sources is completely identified with respect to the heating/cooling plant, AHU, terminal unit, building thermal load (indoor environment), and effect of outdoor environment. Figure 4 shows the component hierarchy for the detailed energy analysis by equipment, system, or purpose of use according to the energy flow [27].

Table 3. Identify relevant factors for the energy audit of hospital buildings.

\begin{tabular}{|c|c|c|c|}
\hline & & \multicolumn{2}{|c|}{ Energy-Related Factors } \\
\hline \multicolumn{2}{|l|}{ Outside environment } & (1) Temperature (DB/WB) & (2) Humidity (RH) \\
\hline \multicolumn{2}{|l|}{ Thermal load } & $\begin{array}{l}\text { (1) Set temperature (DB) } \\
\text { (3) Intake outdoor airflow rate }\end{array}$ & (2) Set related humidity $(\mathrm{RH})$ \\
\hline \multirow[t]{2}{*}{ HVAC system } & Air-conditioning & $\begin{array}{l}\text { (1) Supply air (SA) temp./enthalpy } \\
\text { (3) Air flow rate (CMH) } \\
\text { (5) Coil leaving water temp. } \\
\text { (7) Hot/chilled water flow rate }\end{array}$ & $\begin{array}{l}\text { (2) Return air (RA) temp./enthalpy } \\
\text { (4) OA flow rate (damper) (\%) } \\
\text { (6) Coil entering water temp. }\end{array}$ \\
\hline & Fans & (1) Fan power & \\
\hline \multirow{3}{*}{ Plant system } & Chiller/Boiler & $\begin{array}{l}\text { (1) Equipment leaving water temp. } \\
\text { (3) Hot/chilled water flow rate }\end{array}$ & $\begin{array}{l}\text { (2) Equipment entering water temp. } \\
\text { (4) System efficiency/COP }\end{array}$ \\
\hline & Cooling tower & $\begin{array}{l}\text { (1) Outdoor wet-bulb temperature } \\
\text { (3) Entering condenser water temp. }\end{array}$ & $\begin{array}{l}\text { (2) Leaving condenser water temp. } \\
\text { (4) Cooling tower fan power }\end{array}$ \\
\hline & Water distribution & (1) Pump power & \\
\hline \multicolumn{2}{|l|}{ Energy consumption } & (1) Gas(LNG) consumption & $\begin{array}{ll}\text { (1) Gas(LNG) consumption } & \text { (2) Electricity consumption } \\
\end{array}$ \\
\hline Energy-related equations & $\begin{array}{l}\text { 1. SHF, sensible hea } \\
\text { 2. } Q_{S P}: \text { Space thern } \\
\text { 3. } Q_{V E N}: \text { Ventilatio } \\
\text { 4. Cooling loads } \propto \\
\text { 5. Heating loads } \propto \\
\text { 6. Humidity loads } \\
\text { 7. } Q_{C O I L}: \text { Secondar } \\
\text { water flow rate } \times \text { cc } \\
\text { 8. } E_{A D}: \text { Air distribu } \\
\text { 9. } Q_{H P} / Q_{C P}: \text { Primar } \\
\times \text { Equipment leavin } \\
\text { 10. } E_{H P} / E_{C P}: \text { Input } \\
\text { 11. } \eta_{\text {MP }} / \eta_{C P}: \text { System } \\
\text { 12. Range }=\text { Enterin } \\
\text { 13. Approach }=\text { Lea } \\
\text { 14. Efficiency }=\text { Ran } \\
\text { 15. } E_{C T}: \text { Cooling To } \\
\text { 16. } E_{W D}: \text { Water dist } \\
\text { 17, } \eta_{C T}: \text { System effi } \\
\text { 18. Energy consum } \\
\text { 19 EUI (Energy Use }\end{array}$ & $\begin{array}{l}\rightarrow \text { Initial input required by design } \\
\text { + Energy demand } \\
\text { - Fresh air intake } \\
v \text { rate } \times \text { SA/RA enthalpy difference } \\
v \text { rate } \times \text { SA/RA temperature differen } \\
\text { ow rate } \times \text { OA/SA absolute humid dif } \\
\text { n load: Cooling/heating system load } \\
\text { erature difference } \\
\text { ergy, } L_{A D} \text { : Air distribution loss } \\
\text { m load } \propto \text { Hot/chilled water flow rate } \\
\text { ing water temperature difference } \times \\
\propto \text { Primary system load } \times \text { System effi } \\
\text { ncy (Cooling/Heating) } \\
\text { enser water temp. - Leaving condens } \\
\text { ondenser water temp. - Air wet bulb } \\
\text { Range }+ \text { Approach) } \\
\text { iciency energy (Cooling/Heating) } \\
\text { n energy } \\
\text { Calculated input energy } \times \text { Primary en } \\
\text { ity) }=\text { Energy consumption } \div \text { A } / C \text { are }\end{array}$ & $\begin{array}{l}\text { ata } \\
\text { erence } \\
=\text { AHU coil capacity } \propto \text { Hot/chilled } \\
\text { Ieat loss } \\
\text { iency (COP) } \\
\text { er water temp. } \\
\text { emp. } \\
\text { ergy factor }\end{array}$ \\
\hline
\end{tabular}

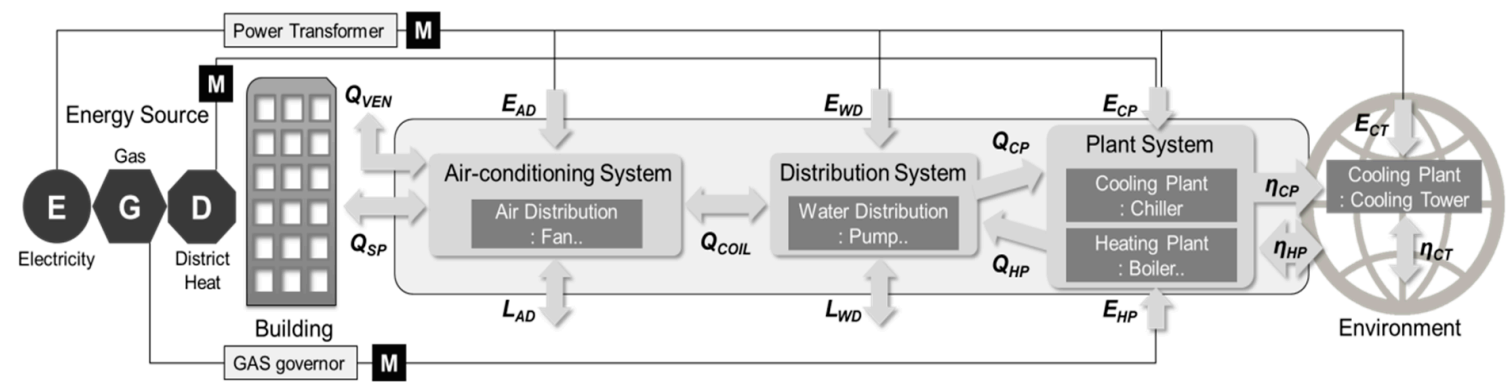

Figure 4. Energy use aggregation levels of energy sub-systems in hospital buildings [27].

\subsection{Stage 4: Detailed Energy Analysis Method of Hospital Building}

Since hospital buildings have very high daily and annual operating hours and large energy consumption of HVAC systems compared to other types of buildings, it is necessary to make plans in the design stage to shorten the operating hours of maximum load and facilitate effective responses 
for partial load operation. Therefore, analyses of operation data are required whereby the physical characteristics and equipment status of medical facility are taken into account. The energy analyses are classified basically into the real-time evaluation and period evaluation. The real-time evaluation determines the normal/abnormal operation status through past operation statuses of equipment and various measurement factors by performing the analysis of measured data for continuous operation of more than certain hours or operations of more than a certain number of times outside of margin of error.

The Judgment criteria are classified generally into the empirical value, initial value, rated value, standard value, and theoretical value, and they should be compared with the basic unit statistics and benchmark indices of medical facility. The period evaluation is the factor analysis that determines more accurate performance of equipment through complex analysis of items. It analyzes the energy loads and demand profiles based on the process/service analysis provided from the system by checking whether a recurrence pattern or seasonal consumption exists. Furthermore, it has a process of trend analysis that determines more accurate performance of equipment through complex analysis between the period evaluation items. The trend analysis method of the corresponding factor for determination of the hospital building energy consumption performs the equipment-oriented detailed evaluation that can identify the energy consumption patterns by equipment. In Table 4 , the energy-related factors and performance evaluation items were derived by equipment, and the variation ranges were defined through the measured values, calculated values based on the measured values, and reference values. Moreover, as shown in Tables 5 and 6, the trend analysis items examined for energy use estimation facilitate the trend analysis and analysis by item based on the real collected operation data. The amount of energy used can be predicted by examining the changes in energy consumption based on the set values of factors. Basically, the normal/abnormal operation should be determined first, and the analysis period is set weekly, monthly, or annually according to the load rate $(40 \%, 60 \%, 80 \%$ and $100 \%)$, and the variation ranges of factors are examined to improve the appropriate energy efficiency. Here, the data processing method such as determining the ranges of including or discarding data, and the linking method with the BEMS program should be investigated.

Table 4. Energy-related factors and performance evaluation items (by equipment).

\begin{tabular}{|c|c|c|c|c|c|}
\hline \multirow{3}{*}{$\begin{array}{c}\text { Equipment } \\
\text { (1) Direct-fired absorption } \\
\text { chiller \& heater (cooling) }\end{array}$} & \multirow{2}{*}{$\begin{array}{c}\text { Energy-Related Factors } \\
\text { CHW flow rate }\left(G_{c h w}\right)\end{array}$} & \multicolumn{2}{|c|}{ Measure } & \multirow{2}{*}{$\begin{array}{l}\text { Reference Value } \\
\text { Initial measured }\end{array}$} & \multirow{2}{*}{$\begin{array}{c}\text { Ranges } \\
\pm 20 \%\end{array}$} \\
\hline & & S & $\mathrm{m}^{3} / \mathrm{h}$ & & \\
\hline & Entering CHW temp. $\left(t_{e-c h w}\right)$ & S & ${ }^{\circ} \mathrm{C}$ & Rated $\left(7^{\circ} \mathrm{C}\right)$ & - \\
\hline & Leaving CHW temp. $\left(t_{l-c h w}\right)$ & S & ${ }^{\circ} \mathrm{C}$ & Setting & $\pm 20 \%$ \\
\hline & $\mathrm{CW}$ flow rate $\left(G_{c w}\right)$ & $\mathrm{S}$ & $\mathrm{m}^{3} / \mathrm{h}$ & Initial measured & $\pm 20 \%$ \\
\hline & Entering CW temp. $\left(t_{e-c w}\right)$ & $\mathrm{S}$ & ${ }^{\circ} \mathrm{C}$ & Setting $\left(37^{\circ} \mathrm{C}\right)$ & $>36^{\circ} \mathrm{C}$ \\
\hline & Leaving CW temp. $\left(t_{l-c w}\right)$ & S & ${ }^{\circ} \mathrm{C}$ & Rated & $<21^{\circ} \mathrm{C}$ \\
\hline & Power consumption $\left(A_{w^{\prime}}\right)$ & $\mathrm{S}$ & $\mathrm{kW}$ & Rated & - \\
\hline & Gas consumption $\left(A_{w \prime}\right)$ & $\mathrm{S}$ & $\mathrm{Nm}^{3} / \mathrm{h}$ & Rated & - \\
\hline & Chiller COP & $\mathrm{SC}$ & - & Rated & - \\
\hline & Heat load rate & SC & $\%$ & - & $50-100 \%$ \\
\hline & Heat balance & $\mathrm{SC}$ & $\%$ & - & - \\
\hline & IPLV & SC & - & - & - \\
\hline & Annual COP profile & $\mathrm{SC}$ & - & by entering $\mathrm{CW}$ temp. & - \\
\hline \multirow{9}{*}{$\begin{array}{l}\text { (2) Direct-fired absorption } \\
\text { chiller \& heater (heating) }\end{array}$} & HW flow rate $\left(G_{h w}\right)$ & S & $\mathrm{m}^{3} / \mathrm{h}$ & Initial measured & $\pm 20 \%$ \\
\hline & Entering HW temp. $\left(t_{e-h w}\right)$ & S & ${ }^{\circ} \mathrm{C}$ & Rated $\left(55^{\circ} \mathrm{C}\right)$ & \\
\hline & Leaving HW temp. $\left(t_{l-h w}\right)$ & S & ${ }^{\circ} \mathrm{C}$ & Setting & $\pm 20 \%$ \\
\hline & Power consumption $\left(A_{w^{\prime}}\right)$ & S & $\mathrm{kW}$ & Rated & $\pm 20 \%$ \\
\hline & Gas consumption $\left(A_{w^{\prime \prime}}\right)$ & S & $\mathrm{Nm}^{3} / \mathrm{h}$ & Rated & - \\
\hline & Heater efficiency & SC & - & Rated & - \\
\hline & Heat load rate & SC & $\%$ & - & $50-100 \%$ \\
\hline & IPLV & SC & - & - & - \\
\hline & Annual efficiency profile & $\mathrm{SC}$ & - & - & - \\
\hline
\end{tabular}


Table 4. Cont.

\begin{tabular}{|c|c|c|c|c|c|}
\hline \multirow{3}{*}{$\begin{array}{c}\text { Equipment } \\
\text { (3) Centrifugal } \\
\text { and screw chillers }\end{array}$} & \multirow{2}{*}{$\begin{array}{c}\text { Energy-Related Factors } \\
\text { CHW flow rate }\left(G_{c h w}\right)\end{array}$} & \multicolumn{2}{|c|}{ Measure } & \multirow{2}{*}{$\begin{array}{c}\text { Reference Value } \\
\text { Initial measured }\end{array}$} & \multirow{2}{*}{$\begin{array}{c}\text { Ranges } \\
\pm 20 \%\end{array}$} \\
\hline & & S & $\mathrm{m}^{3} / \mathrm{h}$ & & \\
\hline & Entering CHW temp. $\left(t_{e-c h w}\right)$ & S & ${ }^{\circ} \mathrm{C}$ & Rated $\left(7^{\circ} \mathrm{C}\right)$ & - \\
\hline & Leaving CHW temp. $\left(t_{l-c h w}\right)$ & S & ${ }^{\circ} \mathrm{C}$ & Setting & $\pm 20 \%$ \\
\hline & CW flow rate $\left(G_{c w}\right)$ & S & $\mathrm{m}^{3} / \mathrm{h}$ & Initial measured & $\pm 20 \%$ \\
\hline & Entering $C W$ temp. $\left(t_{e-c w}\right)$ & S & ${ }^{\circ} \mathrm{C}$ & Setting $\left(37^{\circ} \mathrm{C}\right)$ & $>36^{\circ} \mathrm{C}$ \\
\hline & Leaving CW temp. $\left(t_{l-c w}\right)$ & S & ${ }^{\circ} \mathrm{C}$ & Rated & $<21^{\circ} \mathrm{C}$ \\
\hline & Power consumption $\left(A_{w^{\prime}}\right)$ & S & $\mathrm{kW}$ & Rated & - \\
\hline & Chiller COP & $\mathrm{SC}$ & - & Rated & - \\
\hline & Heat load rate & SC & $\%$ & - & $50-100 \%$ \\
\hline & Heat balance & $\mathrm{SC}$ & $\%$ & - & - \\
\hline & IPLV & $\mathrm{SC}$ & - & - & - \\
\hline & Annual COP profile & $\mathrm{SC}$ & - & by entering $\mathrm{CW}$ temp. & - \\
\hline \multirow[t]{9}{*}{ (4) Cooling tower } & CW flow rate $\left(G_{c w}\right)$ & S & $\mathrm{m}^{3} / \mathrm{h}$ & Initial measured & $\pm 20 \%$ \\
\hline & Entering $\mathrm{CW}$ temp. $\left(t_{e-c w}\right)$ & S & ${ }^{\circ} \mathrm{C}$ & Setting $\left(37^{\circ} \mathrm{C}\right)$ & $>36{ }^{\circ} \mathrm{C}$ \\
\hline & Leaving CW temp. $\left(t_{l-c w}\right)$ & S & ${ }^{\circ} \mathrm{C}$ & Rated & $<21^{\circ} \mathrm{C}$ \\
\hline & Entering DB temp. $\left(t_{e-D B}\right)$ & S & ${ }^{\circ} \mathrm{C}$ & - & - \\
\hline & Entering WB temp. $\left(t_{e-W B}\right)$ & S & ${ }^{\circ} \mathrm{C}$ & - & - \\
\hline & Fan power consumption $\left(A_{w^{\prime}}\right)$ & S & $\mathrm{kW}$ & Rated & - \\
\hline & Range & $\mathrm{SC}$ & - & - & - \\
\hline & Approach & $\mathrm{SC}$ & - & - & - \\
\hline & Cooling tower efficiency & $\mathrm{SC}$ & - & - & - \\
\hline \multirow[t]{8}{*}{ (5) Hot water boiler } & HW flow rate $\left(G_{h w}\right)$ & S & $\mathrm{m}^{3} / \mathrm{h}$ & Initial measured & $\pm 20 \%$ \\
\hline & Entering HW temp. $\left(t_{e-h w}\right)$ & S & ${ }^{\circ} \mathrm{C}$ & Rated $\left(60^{\circ} \mathrm{C}\right)$ & - \\
\hline & Leaving HW temp. $\left(t_{l-h w}\right)$ & S & ${ }^{\circ} \mathrm{C}$ & Setting & $\pm 20 \%$ \\
\hline & Gas consumption $\left(A_{w^{\prime \prime}}\right)$ & $\mathrm{S}$ & $\mathrm{N} \mathrm{m}^{3} / \mathrm{h}$ & Rated & - \\
\hline & Boiler efficiency & $\mathrm{SC}$ & - & Rated & - \\
\hline & Heat load rate & SC & $\%$ & - & $50-100 \%$ \\
\hline & IPLV & $\mathrm{SC}$ & - & - & - \\
\hline & Annual efficiency profile & SC & - & - & - \\
\hline \multirow[t]{7}{*}{ (6) Steam boiler } & Steam flow rate $\left(G_{S}\right)$ & S & $\mathrm{kg} / \mathrm{h}$ & Initial measured & $\pm 20 \%$ \\
\hline & Steam pressure $\left(P_{S}\right)$ & S & $\mathrm{kg} / \mathrm{cm}^{2}$ & Rated & - \\
\hline & Gas consumption $\left(A_{w^{\prime \prime}}\right)$ & S & $\mathrm{Nm}^{3} / \mathrm{h}$ & Rated & - \\
\hline & Boiler efficiency & $\mathrm{SC}$ & - & Rated & - \\
\hline & Heat load rate & $\mathrm{SC}$ & $\%$ & - & $50-100 \%$ \\
\hline & IPLV & SC & - & - & - \\
\hline & Annual efficiency profile & SC & - & - & - \\
\hline \multirow[t]{10}{*}{ (7) Air Handling Unit (AHU) } & SA flow rate $\left(G_{s a}\right)$ & S & $\mathrm{m}^{3} / \mathrm{h}$ & Initial measured & $\pm 20 \%$ \\
\hline & RA flow rate $\left(G_{r a}\right)$ & S & $\mathrm{m}^{3} / \mathrm{h}$ & Initial measured & $\pm 20 \%$ \\
\hline & OA flow rate $\left(G_{o a}\right)$ & S & $\mathrm{m}^{3} / \mathrm{h}$ & Setting & - \\
\hline & Coil CHW flow rate $\left(G_{c h w}\right)$ & S & $\mathrm{m}^{3} / \mathrm{h}$ & Initial measured & $\pm 20 \%$ \\
\hline & Coil HW flow rate $\left(G_{h w}\right)$ & S & $\mathrm{m}^{3} / \mathrm{h}$ & Initial measured & $\pm 20 \%$ \\
\hline & Entering CHW temp. $\left(t_{e-c h w}\right)$ & $\mathrm{S}$ & ${ }^{\circ} \mathrm{C}$ & Setting $\left(7^{\circ} \mathrm{C}\right)$ & - \\
\hline & Leaving CHW temp. $\left(t_{l-c h w}\right)$ & $\mathrm{S}$ & ${ }^{\circ} \mathrm{C}$ & Setting & $\pm 20 \%$ \\
\hline & Entering HW temp. $\left(t_{e-h w}\right)$ & S & ${ }^{\circ} \mathrm{C}$ & Setting $\left(55^{\circ} \mathrm{C}\right)$ & - \\
\hline & Leaving HW temp. $\left(t_{l-h w}\right)$ & $\mathrm{S}$ & ${ }^{\circ} \mathrm{C}$ & Setting & $\pm 20 \%$ \\
\hline & ATF (Air transfer factor) & SC & - & - & - \\
\hline \multicolumn{6}{|c|}{ S: Measured value, SC: Calculated value } \\
\hline
\end{tabular}

In the next stage, the effect of the factors on the energy performance should be verified. First, the mutual energy consumption effect between the factors according to the simplified system configuration can be investigated by using an energy simulation tool. In other words, the changes in energy consumption due to changes set values of the factors can be effectively determined. Lastly, for the building energy consumption estimation, by comparing the variation trend between the operation data and the simulation tool based on the changes of the same factors, their similarity is investigated. Next, by using the energy simulation tool, the energy consumption of the building can be estimated according to the changes of the factors by equipment. 
Table 5. Energy-related factors and performance evaluation items (for energy trend analysis).

\begin{tabular}{|c|c|c|c|c|}
\hline Equipment & Energy-Related Factors & X-Axis & Y-Axis & Data Type \\
\hline (1) Chiller & Entering $\mathrm{CHW}$ temp. versus heat load rate & Heat load rate & $\begin{array}{l}\text { Entering CHW } \\
\text { temp. }\end{array}$ & Monthly \\
\hline \multirow[t]{7}{*}{ (Common) } & \multirow[t]{2}{*}{ COP versus heat load rate } & Heat load rate & COP & Monthly \\
\hline & & Heat load rate & $\mathrm{COP}$ & by CW temp. \\
\hline & \multirow[t]{2}{*}{ Entering CW temp. versus COP } & Entering CW temp. & $\mathrm{COP}$ & by heat load rate \\
\hline & & Entering $\mathrm{CW}$ temp. & $\mathrm{COP}$ & Monthly \\
\hline & Entering $\mathrm{CHW}$ temp. versus COP & Entering CHW temp. & $\mathrm{COP}$ & by heat load rate \\
\hline & COP versus outdoor air temp. & Outdoor air temp. & $\mathrm{COP}$ & Monthly \\
\hline & COP versus leaving $\mathrm{CHW}$ temp. & Leaving CHW temp. & $\mathrm{COP}$ & - \\
\hline (2) Boiler & Entering $\mathrm{HW}$ temp. versus heat load rate $(\mathrm{H})$ & Heat load rate & Entering HW temp. & Monthly \\
\hline Hot-water(H) & Efficiency versus leaving HW temp.(H) & Leaving HW temp. & Efficiency & - \\
\hline \multirow[t]{4}{*}{ Steam $(S)$} & Entering $\mathrm{HW}$ temp. versus efficiency $(\mathrm{H})$ & Entering HW temp. & Efficiency & by heat load rate \\
\hline & Efficiency versus steam pressure (S) & Steam pressure & Efficiency & - \\
\hline & Efficiency versus heat load rate & Heat load rate & Efficiency & Monthly \\
\hline & Efficiency versus outdoor air temp. & Outdoor air temp. & Efficiency & Monthly \\
\hline \multirow{3}{*}{$\begin{array}{l}\text { (3) Cooling } \\
\text { tower }\end{array}$} & (Chiller) heat load rate versus efficiency & Heat load rate & Efficiency & - \\
\hline & Efficiency versus entering WB temp. & Efficiency & Entering WB temp. & - \\
\hline & Ranged versus entering WB temp. & Entering CW temp. & Entering WB temp. & - \\
\hline \multirow[t]{4}{*}{ (4) AHU } & Coil entering/leaving $\Delta T(\mathrm{CHW} \& \mathrm{HW})$ & Entering/leaving $\Delta T$ & Operating time & - \\
\hline & AFT versus outdoor air temp. & Outdoor air temp. & AFT & - \\
\hline & Water entering/leaving $\Delta T(\mathrm{CHW} \& \mathrm{HW})$ & Entering/leaving $\Delta T$ & & - \\
\hline & versus air entering/leaving $\Delta T$ (SA \& RA) & & SA \& RA $\Delta T$ & \\
\hline
\end{tabular}

Table 6. Energy-related factors and performance evaluation items (for energy consumption analysis).

\begin{tabular}{|c|c|c|c|c|}
\hline & Energy-Related Factors & X-Axis & Y-Axis (1) & Y-Axis (2) \\
\hline \multirow{5}{*}{ Each equipment } & Total energy consumption & Total operating hour & Energy consumption & - \\
\hline & Energy consumption & Hour & Energy consumption & Average air temp. \\
\hline & $\begin{array}{l}\text { versus average daily } \\
\text { outdoor air temp. }\end{array}$ & - & - & - \\
\hline & $\begin{array}{l}\text { Energy consumption for the } \\
\text { relevant year }\end{array}$ & Hour & Energy consumption & - \\
\hline & $\begin{array}{l}\text { Energy consumption for the } \\
\text { past year }\end{array}$ & Year & Energy consumption & - \\
\hline
\end{tabular}

\subsection{Stage 5: Discovering Energy Saving Operation Factors According to the Characteristics of Medical Facility}

To estimate the practical and objective energy consumption reduction, the procedure and method based on the prescribed measurement method are used. By discovering the ECMs suitable for hospital buildings and evaluating the annual energy savings based on the statistical analysis technique, the expected benefits of the energy saving item application can be derived [28]. The energy consumption amount of the reference year is selected as a baseline. An energy flow map that links the supply source and usage by energy source is composed, and the energy use status is evaluated with respect to the monitored locations for the supply-consumption amount management. Based on the constructed energy flow, the balance is examined between the supply and consumption by the purpose of use and by place of use. Furthermore, by investigating the problems and appropriateness of the energy balance between supply and consumption, the improvement factors are discovered and the energy reduction technology is selected. To this end, a priority matrix method can be applied, which can evaluate the priorities of ECMs. ECMs can be approached mainly in the aspects of efficiency management, control management, and load management. Moreover, by considering the requirements of hospitals, the priorities of respective energy saving factors can be derived based on the major weighted scales of energy consumption, energy cost, indoor environment, additional cost, and applicability. The weighted values should be established by discussing based on the characteristics of the project.

\section{Analysis of Energy Consumption and Effect of Hospital Buildings by Case Study}

In order to investigate the status of the hospital facility and energy usage pattern, a case study was conducted to select for medium-sized hospitals. After analyzing the status of facilities including detailed use of the facilities, utilization rate and operation time, we set the basic directions for finding 
energy saving factors according to the characteristics of hospital facilities based on energy usage patterns and operation methods.

\subsection{Status of Target Hospitals}

Four hospitals located in Seoul with a large scale of 30,000-100,000 square meters for analysis of energy consumption were selected, which were completed from 1991 to 2011 as shown in Table 7. There was no hospital that exceeded the actual service life due to continuous renovation and expansion. Energy sources included electricity, city gas, local heat sources and a few renewable energy sources. In general, the heating and cooling systems are determined by the energy sources such as electricity, city gas, district heating, etc. Since the steam was required to supply for various purposes in a hospital facility, a steam boiler was usually installed. The main air conditioning system adopted a fan coil unit (FCU) and air handling unit (AHU) to meet the minimum outdoor air requirements. These hospital buildings can be divided into ward, outpatient, operating room, central plant, emergency room, public area, and an office. Each room has a different floor area with the purpose of use. Usage time is also different with the purpose of the room, and it is generally operated in the daytime (8-12 hours) or for 24 hours. Table 8 shows the ratio of the hospital building area to the floor area. As a result of the total hospital floor area of four hospitals, the 24-hour wardroom and 10-hour outpatient department occupied the largest area. Specifically, the wardroom area of hospital A, B, C and D accounted for $24.6 \%, 24.1 \%, 69.1 \%$ and $42.9 \%$ of the total area, respectively. For the area of the outpatient department, hospital A, B, C and D accounted for $25.4 \%, 26.9 \%, 13.5 \%$ and $15.1 \%$ of the total area, respectively. The next largest areas of hospital buildings were the central plant, the public area, the operating room, the business department, the funeral department, and the emergency department. It is necessary to review the energy saving techniques and to determine the priority of them based on the energy consumption of each facility on site as well as the efficiency and effectiveness. Generally, the system occupying a large area becomes a priority target.

Table 7. Reference hospitals for the case study.

\begin{tabular}{|c|c|c|c|c|}
\hline Category & Hospital A & Hospital B & Hospital C & Hospital D \\
\hline \multicolumn{5}{|l|}{ Building features } \\
\hline Year built & 2011 & 1991 & 2004 & 2011 \\
\hline Location & Seoul, Korea & Seoul, Korea & Seoul, Korea & Seoul, Korea \\
\hline Total area & $100,121 \mathrm{~m}^{2}$ & $75,000 \mathrm{~m}^{2}$ & $30,306 \mathrm{~m}^{2}$ & $39,263 \mathrm{~m}^{2}$ \\
\hline Number of floors & $\mathrm{B} 4 \mathrm{~F} / 13 \mathrm{~F}$ & $\mathrm{~B} 3 \mathrm{~F} / 8 \mathrm{~F}$ & $\mathrm{~B} 2 \mathrm{~F} / 7 \mathrm{~F}$ & $\mathrm{~B} 4 \mathrm{~F} / 8 \mathrm{~F}$ \\
\hline Energy source & $\begin{array}{l}\text { Electricity, city gas } \\
\text { and district heating }\end{array}$ & $\begin{array}{l}\text { Electricity } \\
\text { and city gas }\end{array}$ & $\begin{array}{l}\text { Electricity } \\
\text { and city gas }\end{array}$ & $\begin{array}{l}\text { Electricity, city gas } \\
\text { and district heating }\end{array}$ \\
\hline Heating plant & District heating & $\begin{array}{l}\text { Direct-fired absorption } \\
\text { chiller/heater }\end{array}$ & $\begin{array}{l}\text { Heat (steam) } \\
\text { exchanger }\end{array}$ & District heating \\
\hline Cooling plant & $\begin{array}{l}\text { HW driven absorption } \\
\text { chiller }\end{array}$ & $\begin{array}{c}\text { Direct-fired absorption } \\
\text { chiller/heater \& } \\
\text { Absorption chiller }\end{array}$ & Absorption chiller & Absorption chiller \\
\hline Domestic hot water & District heating & $\begin{array}{l}\text { Heat (steam) } \\
\text { exchanger }\end{array}$ & $\begin{array}{l}\text { Heat (steam) } \\
\text { exchanger }\end{array}$ & District heating \\
\hline Steam & $\begin{array}{l}\text { Once-through } \\
\text { steam boiler }\end{array}$ & $\begin{array}{l}\text { Furnace smoke tube } \\
\text { \& Once-through } \\
\text { steam boiler }\end{array}$ & $\begin{array}{l}\text { Furnace smoke tube } \\
\text { \& Once-through } \\
\text { steam boiler }\end{array}$ & $\begin{array}{l}\text { Furnace smoke } \\
\text { tube steam boiler }\end{array}$ \\
\hline $\begin{array}{l}\text { Major HVAC } \\
\text { system }\end{array}$ & $\mathrm{FCU}+\mathrm{AHU}$ & $\mathrm{FCU}+\mathrm{AHU}$ & $\mathrm{FCU}+\mathrm{AHU}$ & $\mathrm{FCU}+\mathrm{AHU}$ \\
\hline System features & & & & \\
\hline
\end{tabular}


Table 8. Zonal floor area ratio of reference hospitals.

\begin{tabular}{|c|c|c|c|c|c|}
\hline Category & Department & Hospital A & Hospital B & Hospital C & Hospital D \\
\hline \multirow{3}{*}{24 hone } & Inpatient (ward room) & $24.6 \%(2)$ & $24.1 \%(2)$ & $69.1 \%(1)$ & $42.9 \%(1)$ \\
\hline & Emergency department & $4.1 \%$ & $5.0 \%$ & $0.7 \%$ & $1.3 \%$ \\
\hline & Funeral services & $5.4 \%$ & $2.8 \%$ & $5.8 \%(3)$ & - \\
\hline \multirow{6}{*}{ 10h zone } & Outpatient services & $25.4 \%(1)$ & $26.9 \%(1)$ & $13.5 \%(2)$ & $15.1 \%(3)$ \\
\hline & Operation theatre & $12.6 \%(4)$ & $7.6 \%$ & $3.2 \%$ & $3.1 \%$ \\
\hline & Central supply department & $15.2 \%(3)$ & $12.2 \%(4)$ & $3.1 \%$ & $8.9 \%(4)$ \\
\hline & Public area \& lobby & $5.8 \%$ & $16.3 \%(3)$ & $4.6 \%(4)$ & $21.4 \%(2)$ \\
\hline & Office & $6.8 \%$ & $3.4 \%$ & - & $4.3 \%$ \\
\hline & Laboratory & - & $1.6 \%$ & - & $2.9 \%$ \\
\hline \multirow{2}{*}{$\begin{array}{c}\text { Zone } \\
\text { features }\end{array}$} & & & & & \\
\hline & Inpatient & $\begin{array}{l}\text { Operation } \\
\text { theatre }\end{array}$ & Central suppl & Public area & Office \\
\hline
\end{tabular}

\subsection{Total Energy Consumption}

The baseline of the total energy consumption of hospitals was collected and analyzed by energy source for the last three years from 2015 to 2017. Although there may be a difference between hospitals, the average energy consumption per unit area of the baseline was $76.1 \mathrm{kgoe} / \mathrm{m}^{2}$. Table 9 shows the energy consumption by the total energy and floor area. Hospital A consumes 4104 TOE per year, 78.3\% of electricity, $12.6 \%$ of district heating and $9.1 \%$ of gas. The average energy use per unit area was 41.0 $\mathrm{kgoe} / \mathrm{m}^{2}$, which is less than half of the average value of medical facilities.

Table 9. Total energy use and energy analysis by energy sources (Level 1).

\begin{tabular}{|c|c|c|c|c|c|c|c|c|c|}
\hline & \multirow{2}{*}{ Category } & \multicolumn{2}{|c|}{ Electricity } & \multicolumn{2}{|c|}{ District Heat } & \multicolumn{2}{|c|}{ Gas(LNG) } & \multicolumn{2}{|c|}{ Baseline } \\
\hline & & kWh & kgoe & kWh & kgoe & $\mathrm{Nm}^{3}$ & kgoe & kgoe & kWh \\
\hline \multirow{2}{*}{ Hospital A } & Total energy use & $14,031,729$ & $3,213,266$ & $6,453,567$ & 516,192 & 363,730 & 374,278 & $4,103,736$ & $46,789,881$ \\
\hline & Ratio by energy source & - & $(78.3 \%)$ & - & $(12.6 \%)$ & - & $(9.1 \%)$ & $(100 \%)$ & - \\
\hline \multirow[b]{2}{*}{ Hospital B } & Total energy use & $22,140,947$ & $5,070,277$ & - & - & $1,906,235$ & $1,961,516$ & $7,031,793$ & $83,725,000$ \\
\hline & Energy use per $\left(\mathrm{m}^{2}\right)$ & 295.2 & 67.6 & - & - & 25.4 & 26.2 & 93.8 & 1116.3 \\
\hline \multirow[t]{2}{*}{ Hospital C } & Energy use per $\left(\mathrm{m}^{2}\right)$ & 118.7 & 27.2 & - & - & 26.2 & 27.0 & 54.2 & 633.7 \\
\hline & Ratio by energy source & - & $(50.2 \%)$ & - & - & - & $(49.8 \%)$ & $(100 \%)$ & - \\
\hline \multirow{3}{*}{ Hospital D } & Total energy use & $5,198,799$ & $1,190,525$ & $4,891,800$ & 391,274 & 165,989 & 170,802 & $1,752,601$ & $19,199,607$ \\
\hline & Energy use per $\left(\mathrm{m}^{2}\right)$ & 132.4 & 30.3 & 124.6 & 10.0 & 4.2 & 4.4 & 44.6 & 489.0 \\
\hline & Ratio by energy source & - & $(67.9 \%)$ & - & $(22.3 \%)$ & - & $(9.7 \%)$ & $(100 \%)$ & - \\
\hline
\end{tabular}

In hospital B, energy consumption has increased by more than 3\% each year for the past three years, and the energy consumption per unit area is $131 \mathrm{kgoe} / \mathrm{m}^{2}$ using $72.1 \%$ of power and $27.9 \%$ more than 1.7 times the energy use. In the case of the elderly care hospital $C$, the energy consumption per unit area is $54.2 \mathrm{kgoe} / \mathrm{m}^{2}$ which is $71.2 \%$ of the average of the medical facilities, and the total energy use is 1641 TOE with $50.2 \%$ of electricity and $49.8 \%$ of gas. Finally, hospital D consumed $67.9 \%$ of electricity, $22.3 \%$ of district heating, $9.7 \%$ of gas, and consumed 1753 TOE per year, $44.6 \mathrm{kgoe} / \mathrm{m}^{2}(59 \%$ of the average). It is difficult to find a normalized pattern of energy consumption because the four target hospitals operate differently considering their medical functional characteristics. Thus, it is necessary to specify the detailed analysis of the energy use rate by facilities and the effective energy flow chart analysis.

\subsection{Detailed Energy Consumption}

First, an energy flow map was created for the monthly energy supply and demand of the target hospital and the detailed energy use status was assessed by the actual measurement for supply and 
demand sides. Then, the energy flow of gas, electricity, and district heating by sources was analyzed. Finally, the energy use ratio and contribution ratio by the system were calculated. Figure 5 shows an example of analyzing various energy flows and system load (energy) contribution of hospital A. Based on this energy flow chart, the energy balance of the supply and consumption for each use can be examined, and the problem of energy flow can be identified. The final step is to determine the improvement and energy reduction technologies.
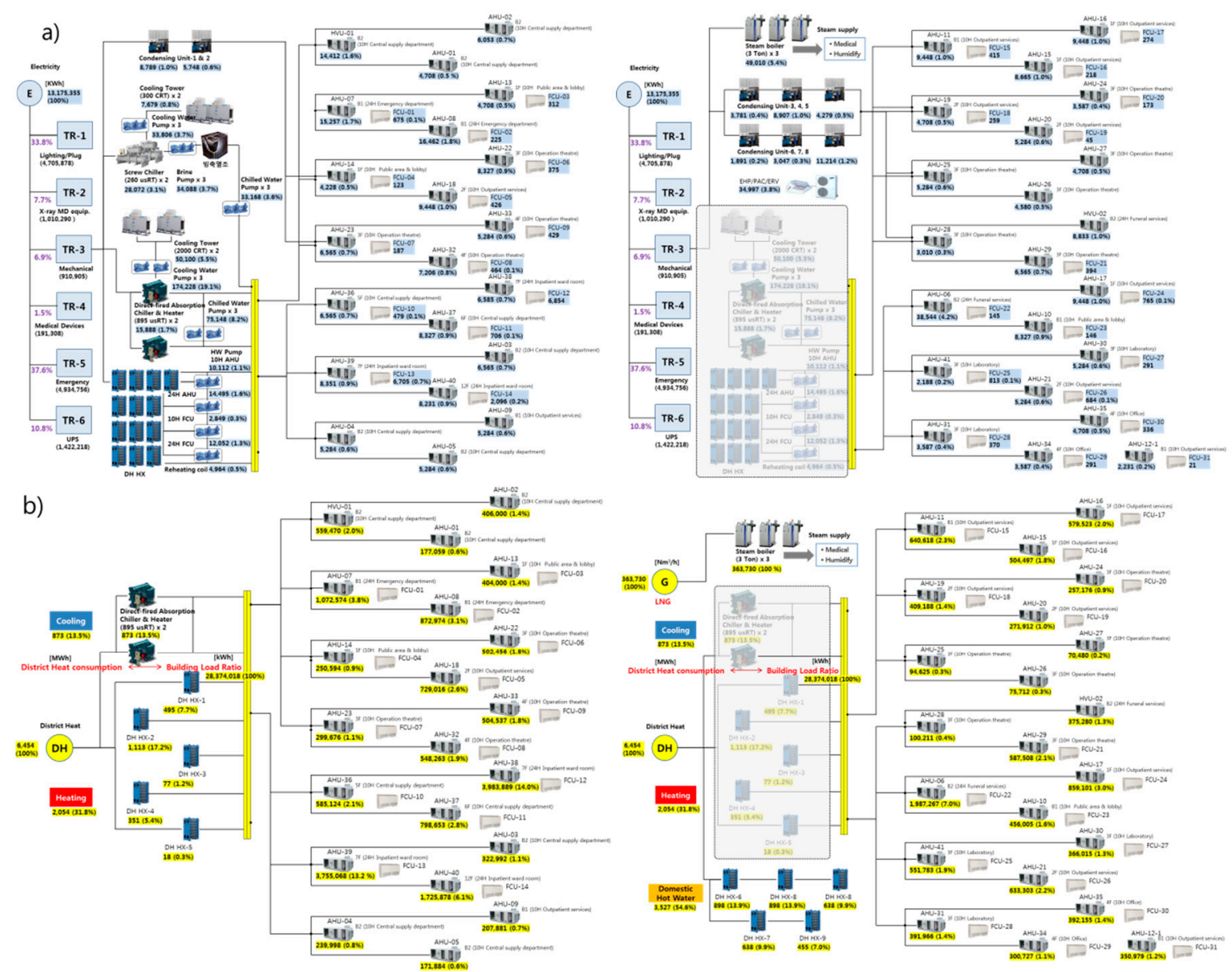

Figure 5. Energy flow charts for a reference hospital A: (a) Electricity and (b) district heat and city gas.

(1) Electricity consumption for use

As shown in Figure 6, hospital A used 33.8\% of its total electricity in lighting/plug, 37.6\% in emergency power and $10.8 \%$ in UPS, $7.7 \%$ in medical equipment, and $6.9 \%$ in machinery power, respectively. Hospital B used 33.5\% of total electricity in lighting/plug, 25.5\% in air-conditioning, and $15.1 \%$ in medical equipment. Hospital C showed similar weight in the order of $27.7 \%$ in air conditioning, 27\% in lighting/plug, $23 \%$ in medical examination and diagnosis equipment and $22.3 \%$ in mechanical power similar to hospital B. Hospital D used $42.6 \%$ of total electricity in lighting/plug, $23.5 \%$ in mechanical power, $14.3 \%$ in medical equipment and $15.3 \%$ of emergency power. 

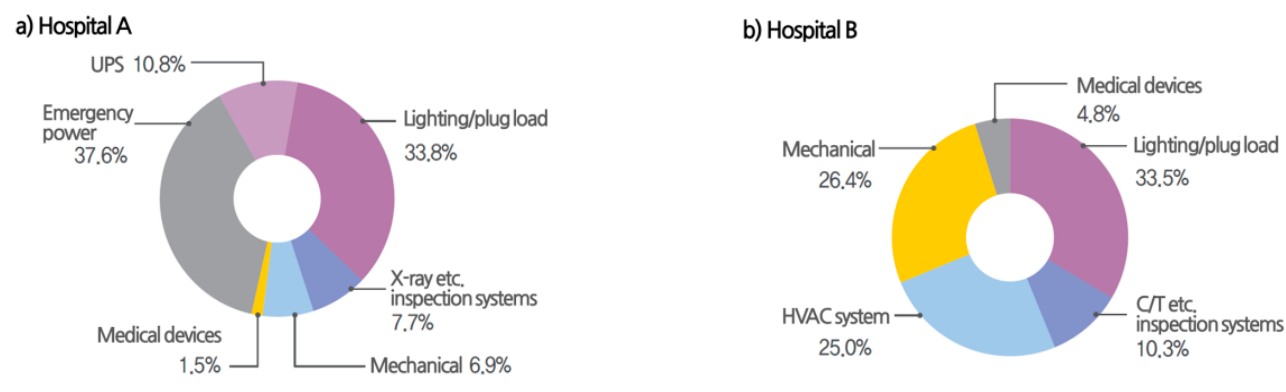

c) Hospital C
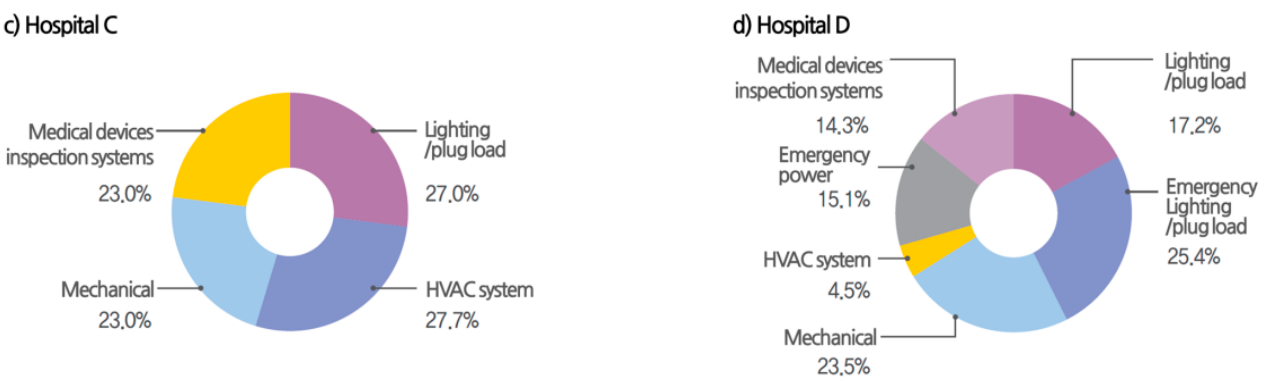

Figure 6. Power usage ratio by systems in reference hospitals.

(2) Thermal energy consumption for the hospital facility

Since the thermal energy consumption of a hospital building should be measured directly by the equipment that supplies the heat source from the central plant, it is very difficult to calculate the amount of heating and cooling energy for each system. Thus, the energy flow map can be used to assess energy usage by each equipment more specifically. Based on the system configuration and equipment list of the four hospitals, the energy consumption ratio of each system was analyzed by the total energy used in the central plant. Figure 7 shows the predicted usage rate of air conditioning, heating and cooling energy by zone. Hospital A consumed $33.4 \%$ of the total thermal energy in the inpatient zone because of the long operating time compared with the area, and $18.3 \%$ in $10 \mathrm{~h}$ of the outpatient zone and $14.2 \%$ in $10 \mathrm{~h}$ of the central supply department, respectively. Hospital B showed the highest energy consumption $54.4 \%$ in the inpatient zone, $12.2 \%$ in the public zone and $9.7 \%$ in the outpatient zone, respectively. The small hospital $\mathrm{C}$ and medium hospital $\mathrm{D}$ consumed the highest energy of $75.2 \%$ in the inpatient zone due to the large floor area and long usage time. Furthermore, energy consumptions in the outpatient zone were $9.1 \%$ in hospital C and $6.0 \%$ in hospital D.
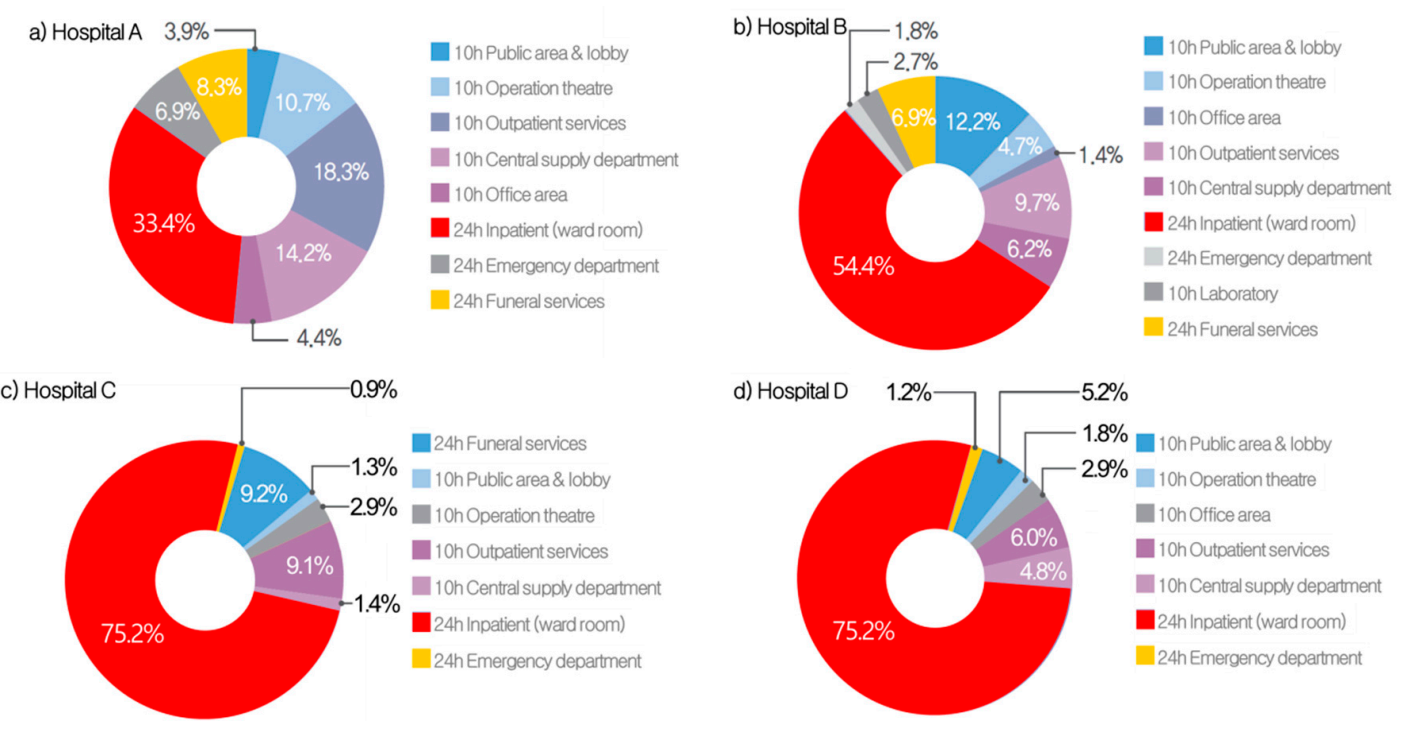

Figure 7. Thermal (heating/cooling) load contribution rate by zones. 
(3) Energy consumption for each HVAC system

As shown in Figure 8, the energy consumption of hospital A using the district heating system was analyzed for $54.6 \%$ of the total district energy in domestic hot water, $31.8 \%$ in heating and $13.5 \%$ in cooling, respectively. For electricity, $48.1 \%$ of the total electricity in circulation pump, $35.2 \%$ of AHU fan, $10.1 \%$ in heat and cooling equipment, $3.8 \%$ in other air-conditioning equipment and $2.9 \%$ in the FCU fan, respectively. Hospital D consumed the energy around $4.5 \%$ of the total district energy in cooling, $28.7 \%$ in domestic hot water $(28.7 \%)$ and heating $(25.8 \%)$. This hospital also consumed the electricity $68.9 \%$ in the circulating pump, $22.1 \%$ in the heat and cooling equipment, $0.8 \%$ in the $\mathrm{AHU}$ and FCU fan, $0.5 \%$ in other air-conditioning equipment, respectively. Hospital B based on the gas heat source consumed $38.4 \%$ of the total gas energy in the once-through steam boiler, $34.7 \%$ in the furnace smoke tube boiler and $26.9 \%$ in the absorption heat pump, respectively. In addition, the electricity of this hospital consumed $67.2 \%$ in the circulation pump, $13.8 \%$ in heating and cooling equipment, $16.6 \%$ in the AHU fan, and 2.3\% in the FCU fan, respectively. Finally, the gas consumption of hospital C was $76.3 \%$ in the furnace smoke tube boiler and $23.7 \%$ in the once-through steam boiler. For electricity, this hospital consumed $40.6 \%$ in the circulation pump, $30.5 \%$ in AHU fan, $27.6 \%$ in heating and cooling equipment, $0.7 \%$ in the FCU fan, and $0.6 \%$ in other air-conditioning equipment, respectively.

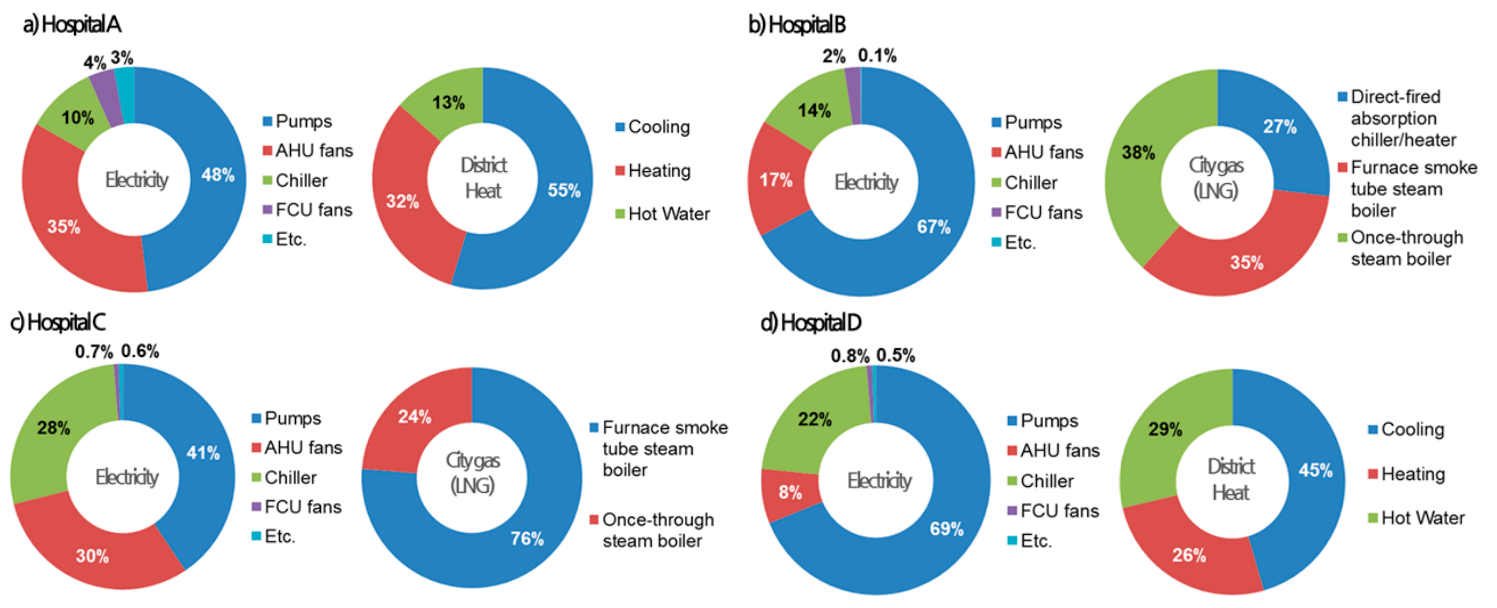

Figure 8. Power and thermal energy usage ratio by equipment in reference buildings.

\subsection{The Differences in Energy Consumption}

Big differences can be seen in the current energy consumptions in each hospital. As a result of the case study on the analysis of the gross and detailed energy consumption in four hospital buildings, the analysis of the energy total amount and the detailed energy usage, there are various obstacles to apply energy saving techniques. In terms of the diversity of the hospital buildings, those are divided into three categories according to the size of the building such as the number of beds, the purpose of use (configuration of the facility area), the energy source, the usage ratio and the equipment configuration. Thus, there is a limit to apply uniform energy saving techniques to these buildings. Table 10 shows the diversity of energy consumption structure by case study. In addition, there are limitations in the system of energy conservation activities of managers and users such as energy consumption level of the hospital, application subject, application target, and application method, scope of application and reduction target in the system of energy saving operation. Therefore, it is important to effectively utilize various energy conservation activities of the medical facility in order to achieve the reduction target by effectively setting it for the hospital, and it is important to accurately understand the energy consumption structure. Energy conservation activities should be the process of realizing energy saving operation according to the characteristics of hospital building thermal load (energy consumption), the use of facilities, and operating pattern. 
Table 10. Comparative assessment of energy usage for reference hospitals.

\begin{tabular}{|c|c|c|c|c|c|}
\hline Category & & Hospital A & Hospital B & Hospital C & Hospital D \\
\hline Total Area & & $100,121 \mathrm{~m}^{2}$ & $75,000 \mathrm{~m}^{2}$ & $30,306 \mathrm{~m}^{2}$ & $39,263 \mathrm{~m}^{2}$ \\
\hline \multirow{3}{*}{$\begin{array}{l}\text { Zonal floor } \\
\text { area ratio }\end{array}$} & 1 & Outpatient (25.4\%) & Outpatient $(26.9 \% \%)$ & Inpatient $(69.1 \%)$ & Inpatient $(42.9 \%)$ \\
\hline & 2 & Inpatient $(24.6 \%)$ & Inpatient $(24.1 \% \%)$ & Outpatient (13.5\%) & Public area $(21.4 \%)$ \\
\hline & 3 & Central supply $(15.2 \%)$ & Public area $(16.3 \%)$ & Funeral services $(5.8 \%)$ & Outpatient $(15.1 \%)$ \\
\hline \multirow{3}{*}{$\begin{array}{l}\text { Energy use } \\
\text { by energy sources }\end{array}$} & 1 & Electricity $(78.3 \%)$ & Electricity $(72.1 \%)$ & Electricity $(50.2 \%)$ & Electricity $(67.9 \%)$ \\
\hline & 2 & District heat (12.6\%) & LNG $(27.9 \%)$ & LNG $(49.8 \%)$ & District heat $(22.3 \%)$ \\
\hline & 3 & LNG $(9.1 \%)$ & - & - & LNG (9.7\%) \\
\hline \multirow{3}{*}{$\begin{array}{l}\text { Energy use } \\
\text { by zone }\end{array}$} & 1 & Inpatient $(33.4 \%)$ & Inpatient $(54.4 \%)$ & Inpatient $(75.2 \%)$ & Inpatient $(78.0 \%)$ \\
\hline & 2 & Outpatient $(18.3 \%)$ & Public area $(12.2 \%)$ & Funeral services $(9.2 \%)$ & Outpatient $(6.0 \%)$ \\
\hline & 3 & Central supply $(14.2 \%)$ & Outpatient $(9.7 \%)$ & Outpatient $(9.1 \%)$ & Public area $(5.2 \%)$ \\
\hline \multirow{3}{*}{$\begin{array}{l}\text { Power usage ratio } \\
\text { by systems }\end{array}$} & 1 & Lighting/plug (33.8\%) & Lighting/plug (33.5\%) & HVAC $(27.7 \%)$ & Lighting/plug (17.2\%) \\
\hline & 2 & HVAC $(6.9 \%)$ & HVAC (25.0\%) & Lighting/plug (27.0\%) & HVAC (4.5\%) \\
\hline & - & Medical devices $(9.2 \%)$ & Medical devices (15.1\%) & Medical devices $(23.0 \%)$ & Medical devices $(14.3 \%)$ \\
\hline \multirow{2}{*}{\multicolumn{2}{|c|}{$\begin{array}{l}\text { Total energy } \\
\text { (baseline) }\end{array}$}} & 4,104 TOE & $7,032 \mathrm{TOE}$ & $1,641 \mathrm{TOE}$ & $1,753 \mathrm{TOE}$ \\
\hline & & $41.0 \mathrm{kgoe} / \mathrm{m}^{2}$ & 93.8 kgoe $/ \mathrm{m}^{2}$ & $54.2 \mathrm{kgoe} / \mathrm{m}^{2}$ & $44.6 \mathrm{kgoe} / \mathrm{m}^{2}$ \\
\hline
\end{tabular}

\section{Discussion and Conclusions}

The use of benchmarking in the energy audit of hospital facilities enables immediate comparison between hospitals. Data driven analysis allows ascertaining their expected energy consumption and estimating the possible savings margin. In the 2015-2017 periods, energy audits of four public hospitals in Seoul analyzed the energy consumption related to weather conditions, total area, bed numbers, employee numbers, and by zones, energy sources, systems and equipment. In this study, energy efficiency factors are divided into energy baselines (Baseline), energy consumption goals for energy saving goals and energy consumption pattern for setting ECMs, respectively. The results of this study are as follows:

(1) The method of the energy audit and data-driven analysis for the hospital building energy saving is largely required to find the energy saving operation factor according to the characteristics of the medical facility through the setting of the energy evaluation standard of the target facility system and the smart energy analysis of the hospital building.

(2) Detailed information on the field survey and preliminary evaluation items and methods, remote measurement energy data collection, energy related factors and performance evaluation items, and detailed analysis method of the energy of the hospital building is presented.

(3) As a result of analyzing the energy structure of four hospitals in Seoul, energy consumption highly varied with the size of building, the area of the used facility, the type of energy source, the usage ratio and the main equipment configuration.

(4) Various energy reduction activities in a hospital building should be prioritized to achieve the reduction target effectively in accordance with the hospital.

(5) As future work, it will be necessary to develop an energy saving operation guideline that can perform effective energy saving activities of the hospital through a procedure to analyze the concrete energy consumption structure of the hospital building.

The indicator dependent on the area of the inpatient (number of beds) proved to be the most suitable as a reference to quantify the energy consumption of a hospital. Although there are many technical methods for improving energy efficiency, a hospital's energy auditors should begin by considering the more simple measures. Improvements or changes made in one energy system can often affect other energy systems. Therefore, thorough systems analysis and consideration is necessary before any modifications are implemented. Data driven monitoring, as much as control of the energy situation, is the key to success. It will provide information from which the technical management can detect malfunctions and make recommendations for further improvements. 
Author Contributions: D.K.H. and J.C. contributed to the research idea, J.C. conducted the analysis, D.K.H. supervised the analysis, J.C. and J.M. wrote the paper, and J.M. reviewed the paper.

Funding: This research received no external funding.

Conflicts of Interest: The authors declare no conflict of interest.

\section{References}

1. Korea Energy Economics Institute. 2014 Energy Consumption Survey; Korea Ministry of Trade, Industry \& Energy: Sejong, Korea, 2015.

2. DOE/EIA-0484, International Energy Outlook 2013; U.S. Energy Information Administration: Washington, DC, USA, 2013.

3. Korea Energy Economics Institute. 2013 Yearbook of Regional Energy Statistics; Korea Ministry of Trade, Industry \& Energy: Sejong, Korea, 2014.

4. Energy Information Administration. Commercial Building Energy Consumption Survey; U.S. Department of Energy: Washington, DC, USA, 2003.

5. Pe'rez-Lombard, L.; Ortiz, J.; Pout, C. A review on buildings energy consumption information. Energy Build. 2008, 40, 394-398. [CrossRef]

6. Bonnema, E.; Studer, D.; Parker, A.; Pless, S.; Torcellini, P. Large Hospital 50\% Energy Savings: Technical Support Document; National Renewable Energy Laboratory: Golden, CO, USA, 2010.

7. 2018 Korea Energy Agency Handbook; Korea Energy Agency: Ulsan, Korea, 2018.

8. Korea Energy Economics Institute. Survey on Energy Consumption in Buildings; Korea Ministry of Trade, Industry \& Energy: Sejong, Korea, 2015.

9. Cho, J.; Moon, J.; Rhee, K.; Kang, H. Energy consumption characteristics of patient room HVAC systems for large hospital buildings in worldwide climate zones. J. Archit. Inst. Korea 2015, 31, 171-180.

10. Cho, J.; Moon, J.; Kang, H. Energy Performance Analysis for Energy Saving Potentials of a Hospital Building: A Case Study Methodology Based on Annual Energy Demand Profiles. Korean J. Air Cond. Refrig. Eng. 2017, 29, 29-37.

11. Biglia, A.; Caredda, F.V.; Fabrizio, E.; Filippic, M.; Mandas, N. Technical-economic feasibility of CHP systems in large hospitals through the Energy Hub method: The case of Cagliari AOB. Energy Build. 2017, 147, 101-112. [CrossRef]

12. Wang, T.; Li, X.; Liao, P.C.; Fang, D. Building energy efficiency for public hospitals and healthcare facilities in China: Barriers and drivers. Energy 2016, 103, 588-597. [CrossRef]

13. Christiansen, N.; Kaltschmitt, M.; Dzukowski, F. Electrical energy consumption and utilization time analysis of hospital departments and large scale medical equipment. Energy Build. 2016, 131, 172-183. [CrossRef]

14. Congradac, V.; Prebiracevic, B.; Petrovacki, N. Methods for assessing energy savings in hospitals using various control techniques. Energy Build. 2014, 69, 85-92. [CrossRef]

15. Ascione, F.; Bianco, N.; Stasio, C.; Mauro, G.M.; Vanoli, G.P. Multi-stage and multi-objective optimization for energy retrofitting a developed hospital reference building: A new approach to assess cost-optimality. Appl. Energy 2016, 174, 37-68. [CrossRef]

16. González, A.; García-Sanz-Calcedo, J.; Salgado, D.R. A quantitative analysis of final energy consumption in hospitals in Spain. Sustain. Cities Soc. 2018, 36, 169-175. [CrossRef]

17. Teke, A.; Timur, O. Assessing the energy efficiency improvement potentials of HVAC systems considering economic and environmental aspects at the hospitals. Renew. Sustain. Energy Rev. 2014, 33, 224-235. [CrossRef]

18. Vanhoudt, D.; Desmedt, J.; Bael, J.V.; Robeyn, N.; Hoes, H. An aquifer thermal storage system in a Belgian hospital: Long-term experimental evaluation of energy and cost savings. Energy Build. 2011, 43, 3657-3665. [CrossRef]

19. Ma, H.; Du, N.; Yu, S.; Lu, W.; Zhang, Z.; Deng, N.; Li, C. Analysis of typical public building energy consumption in northern China. Energy Build. 2017, 136, 139-150. [CrossRef]

20. Papantoniou, S.; Kolokotsa, D.; Kalaitzakis, K. Building optimization and control algorithms implemented in existing BEMS using a web based energy management and control system. Energy Build. 2015, 98, 45-55. [CrossRef] 
21. Lee, D.; Cheng, C. Energy savings by energy management systems: A review. Renew. Sustain. Energy Rev. 2016, 56, 760-777. [CrossRef]

22. Shen, C.; Zhao, K.; Ge, J.; Zhou, Q. Analysis of Building Energy Consumption in a Hospital in the Hot Summer and Cold Winter Area. Energy Procedia 2019, 158, 3735-3740. [CrossRef]

23. Thinate, N.; Wongsapai, W.; Damrongsak, D. Energy Performance Study in Thailand Hospital Building. Energy Procedia 2017, 141, 255-259. [CrossRef]

24. Alonso, S.; Morán, A.; Prada, M.Á.; Reguera, P.; José, J.F.; Domínguez, M. A Data-Driven Approach for Enhancing the Efficiency in Chiller Plants: A Hospital Case Study. Energies 2019, 12, 827. [CrossRef]

25. González, A.; García-Sanz-Calcedo, J.; Salgado, D.R. Evaluation of Energy Consumption in German Hospitals: Benchmarking in the Public Sector. Energies 2018, 11, 2279. [CrossRef]

26. García-Sanz-Calcedo, J.; Gómez-Chaparro, M. Quantitative analysis of the impact of maintenance management on the energy consumption of a hospital in Extremadura (Spain). Sustain. Cities Soc. 2017, 30, 217-222. [CrossRef]

27. Cho, J.; Shin, S.; Kim, J.; Hong, H. Development of an energy evaluation methodology to make multiple predictions of the HVAC\&R system energy demand for office buildings. Energy Build. 2014, 76, 169-183.

28. ASHRAE. Advanced Energy Design Guide for Large Hospitals; American Society of Heating, Refrigerating and Air-Conditioning Engineers, Inc: Atlanta, GA, USA, 2012.

(C) 2019 by the authors. Licensee MDPI, Basel, Switzerland. This article is an open access article distributed under the terms and conditions of the Creative Commons Attribution (CC BY) license (http://creativecommons.org/licenses/by/4.0/). 